\title{
WestVirginiaUniversity
}

THE RESEARCH REPOSITORY @ WVU

Graduate Theses, Dissertations, and Problem Reports

2001

\section{Mass media framing of hip-hop artists and culture}

Marc Allen Rutherford
West Virginia University

Follow this and additional works at: https://researchrepository.wvu.edu/etd

\section{Recommended Citation}

Rutherford, Marc Allen, "Mass media framing of hip-hop artists and culture" (2001). Graduate Theses, Dissertations, and Problem Reports. 1131.

https://researchrepository.wvu.edu/etd/1131

This Thesis is protected by copyright and/or related rights. It has been brought to you by the The Research Repository @ WVU with permission from the rights-holder(s). You are free to use this Thesis in any way that is permitted by the copyright and related rights legislation that applies to your use. For other uses you must obtain permission from the rights-holder(s) directly, unless additional rights are indicated by a Creative Commons license in the record and/ or on the work itself. This Thesis has been accepted for inclusion in WVU Graduate Theses, Dissertations, and Problem Reports collection by an authorized administrator of The Research Repository @ WVU. For more information, please contact researchrepository@mail.wvu.edu. 


\title{
Mass Media Framing of Hip-Hop Artists and Culture
}

\author{
Marc A. Rutherford \\ Thesis submitted to the \\ P.I. Reed School of Journalism \\ at West Virginia University \\ in partial fulfillment of the requirements \\ for the degree of \\ Master of Science \\ in \\ Journalism
}

Terry Wimmer, Ph.D., Chair

Ralph Hanson, Ph.D.

Gwen Bergner, Ph.D.

Maryanne Reed, MSJ

Department of Journalism

Morgantown, West Virginia

2001

Keywords: Mass Media, Framing Theory, Hip-Hop

Copyright 2001 Marc A. Rutherford 


\title{
Abstract \\ Mass Media Framing of Hip-Hop Artists and Culture
}

\author{
Marc A. Rutherford
}

The purpose of the mass news media is to inform individuals and society of important issues and events of the day. This coverage is influenced by the reporter's background, experience, time constraints, and a host of other factors. The way a reporter chooses to cover a particular story gives the story its slant or frame. Examining a cross section of media outlets from around the country gives a more complete picture of how a story is presented to society as a whole. Media coverage of hip-hop culture and the artists associated with it on a national level has been decidedly negative over the past twelve years. From the first rap/hip-hop Grammy win of Jazzy Jeff and the Fresh Prince through the murders of Tupac Shakur and Notorious B.I.G. up to Eminem's nomination for Album of the Year for 2000, hip-hop is framed as "bad boy" music produced mainly by derelicts and criminals. This study examines these frames and analyzes the causes leading to such framing. 


\section{ACKNOWLEDGMENTS:}

I would like to thank Professors Ralph Hanson and Terry Wimmer for their guidance with this project. Your input with regard to resourcing was invaluable to the culmination of this study. I would also like to thank the members of my committee: the aforementioned professors along with Professors Gwen Bergner and Mayanne Reed, for dedicating their time and energy in seeing this project through to its completion.

Many thanks and much love goes to my parents, Jane and John Rutherford, for supporting me in all ways possible during my time at WVU. I will appreciate what you have done for me forever. 


\section{TABLE OF CONTENTS:}

I) INTRODUCTION 1

II) LITERATURE REVIEW 2

a) Framing and Frame Analysis 2

b) A History of Hip-Hop 6

c) An Overview of Media Coverage of Hip-Hop 12

d) A History of American Black Music in the Media 14

III) RESEARCH QUESTION 16

IV) METHODOLOGY 16

V) RESULTS 21

a) Findings for Jazzy Jeff and Fresh Prince 22

b) Findings for 2 Live Crew 23

c) Findings for Tupac Shakur 26

d) Findings for Notorious B.I.G. 28

e) Findings for Combined Murder Coverage 30

f) Findings for Lauryn Hill 32

g) Findings for Eminem 35

h) Overall Findings $\quad 37$

i) Findings for Columns 40

j) Findings for Alternative Press Coverage 43

VI) CONCLUSION 48

VII) TABLES

VIII) BIBLIOGRAPHY (NEWSPAPER ARTICLES) 53

IX) BIBLIOGRAPHY (ALT PRESS COVERAGE) 56

X) BIBLIOGRAPHY (WORKS CITED) 58 


\section{INTRODUCTION:}

Hip-hop is one of the most prominent genres of music on the pop culture scene today. The influence of hip-hop on the mainstream culture can be seen in popular styles of dress, speech patterns, and cultural values. In many ways, hip-hop is this generation's answer to rock and roll in the 1950s and 60s or jazz in the 1920s and 30s. This is music made by young people for young people, drawing a proverbial line in the sand between the younger and older segments of our society. With this idea in mind, the mainstream media's coverage of this music and culture is an indication of how the dominant culture will view this phenomenon. News frames are being set by a generation of mostly older whites not connected to this musical genre or its creators, who are predominantly young Blacks and Latinos. This research chronicles the stories being told about hip-hop by the mainstream media to the dominant culture, exposing what information is provided to viewers of such publications. The importance of identifying these stories is to locate patterns of information that frame hip-hop and those associated with it in a particular way. If viable patterns emerge, they can be utilized to draw wider conclusions and generalizations about mainstream public sentiment of hip-hop artists and culture. 


\section{LITERATURE REVIEW:}

\section{Framing and Frame Analysis}

The theory of media framing has its origins in the study and interpretation of media messages. Beginning in the 1970s with pioneering researcher Erving Goffman, this research has been furthered through the work of Tuchman, Minsky and Altheide, among others, over the past 25 years. In his influential work Frame Analysis, Goffman characterizes frames as a "schemata of interpretation" used to "locate, perceive, identify, and label...what would otherwise be a meaningless aspect of the scene into something that is meaningful" (1974). We are bombarded each day with countless pieces of information, and media framing puts some of these pieces together in a more coherent way. Nelson, et al. define a frame as "the process by which a communication source...defines and constructs a political issue or public controversy," thereby creating the framework for public dialogue on a given topic (1997). Reporters use these frames to sort out and make sense of an overwhelming amount of potential news and information produced every day. Framing is utilized in all media content to the extent that reporters decide which stories are given precedence, and what aspects of those stories are accentuated. Audiences begin to recognize and accept these frames through repeated viewing. Framing sets the parameters through which the public discourse will occur. 
Newspaper reporters write hundreds of stories per year. Certain stories are consistently told in a particular way, fitting the writer's, and usually society's, dominant frame of the story. Researcher Gaye Tuchman found that reporters "set the frame in which citizens discuss public events" and thereby "narrow the available political alternatives" (1978). This is especially true when issues of race are covered by the media. Public opinion drives political action, and if the media shape public opinion to a large extent, the media can affect race-related public policy with their stories (Gissler 1994). While giving the audience the who, what, when, where, why, and how of an event, the author makes personal decisions about what should or should not be included in the details of the story. The writer must decide what type of story is being covered, and to what depth she/he will research the story. Is this a front page story? Should the newspaper put time and resources into further investigation of the event? These are questions that the reporter asks him/herself to determine the brevity or depth of coverage and overall approach to a story. Just as children can imagine alternate endings to stories they tell each other, there is an infinite number of ways the media can frame and arrange stories to produce different messages (Tuchman).

The model Robert Entman used in his analysis of framing in the KAL and Iran Air incidents of the 1980s identifies five criteria that emphasize the overall media framing of a particular story: sizing, agency, identification, categorization, and generalization. Application of these factors in analyzing a news story gives much greater insight into the overall impact the story has on the viewer. These are the primary factors I will be utilizing in my analysis of hip-hop coverage. The style of coverage afforded to hip-hop 
by the media is a reflection of how mainstream society will view hip-hop and those associated with the culture. One of the most important aspects of examining frames is to identify the sources used for the story.

The sources a reporter chooses to utilize greatly impact how a story will ultimately be framed. Many reporters have reliable, long-time sources within the government, police, or public relations establishment that they turn to over and over again for pertinent information. This reliance can skew the reporter's vision of a story toward the status quo; they are receiving information from a relatively small group of people, most of whom have agendas they are hoping to push. Media sources "provid[e] the context within which all other information is evaluated," creating a framework in the reporter's mind from which he/she feels the story should be covered (Shoemaker and Reese 1991). Consequently, alternative viewpoints may be largely overlooked or ignored. This in turn reduces the public's willingness to accept viewpoints outside of the mainstream because the media have designated particular, usually institutional, sources as better or more important than those of outside social commentators. Stories become repetitively framed based largely on the culture of the society in which they occur. "With few exceptions, a nation's news media reflect many cultural and ideological preferences. This general process has been referred to as hegemony" (Altheide 1987). A definition of hegemony for this project is "an order in which a certain way of life and thought is dominant, in which one concept of reality is diffused throughout society, in all its institutions and private manifestations" (Williams 1960). Through the use of hegemonic framing, journalists limit the dissemination of information to the audience, and the public's overall 
knowledge of a news topic is compromised. Hegemonic overtones in a story are not always the result of unintentional cultural blinders. A West Coast reporter was assigned a story on the problems with immigrants "clogging up" the US prison system. "After scratching beneath the surface of a few widely reported but dubious statistics, she uncovered a startling and inconvenient truth: Immigrants are no more prone to crime than the native population. But her bosses didn't want that story" (Miller 1994). She then went on to write the story without including this pertinent information. Such preconceived notions about race illustrate what can happen when hegemonic framing goes unchecked.

The framing of hip-hop culture and hip-hop musicians in the media has received little academic attention and interpretation, and this thesis attempts to further a dialogue about the media's handling of (arguably) the most important musical phenomenon of the last 25 years. This paper is not intended to be an indictment of the media; the intent is to look seriously at what stories are being told about hip-hop and those associated with it, and from what perspective they are being told. By examining stories in major newspapers, which are predominantly staffed by whites, and comparing them to a publication like the Village Voice, which employs a higher percentage of minority writers, I hope to expose the differences in the way stories concerning hip-hop, a culture created by black and Latino urban youth, are covered. Do most blacks agree with the interpretation of the mostly white Washington Post? Professor Andrew Hacker says the "mainstream media speak for a white nation, which expects all citizens to conform to its ways. Black Americans [are told to] cast themselves as the kinds of people whites would 
like blacks to be" (1994). So from this perspective, blacks who do not fit into the "white" world around them are portrayed as trouble-makers and a problem. This research addresses this dichotomy with the emphasis on hip-hop and urban youth culture.

\section{$\underline{\text { A History of Hip-Hop }}$}

A history of hip-hop culture leading up to the "gangsta rap" era is included to exhibit the progression of the phenomenon since its inception. Hip-hop music and culture grew out of predominantly black and Latino neighborhoods of the South Bronx in the mid 1970s. Block parties and house parties would have DJs, and they began talking over the records, giving shout-outs and other messages to keep the party going. From this beginning, hip-hop music has grown into one of the biggest selling genres of music both in the U.S. and internationally.

Hip-hop was born as both a social and an urban experience. Its parents were of African descent - black and brown city dwellers. Among early hip hoppers were a mix of harsh poverty and middle class affluence. People of varied economic backgrounds mixed casually because crack cocaine was still a decade or so away from carving out the economic chasm that currently exists in America's inner cities. Urban life was far from prosperous, but in the 1970s it had not yet bottomed out either. These circumstances instigated the creation of Hip-hop - a very simple organism that acted as a communication device among city folk. It inhaled frustration and desperation and exhaled insightful expression. In its infancy, Hip-hop traveled from its native New York to other American metropolitan hubs. Hip Hop proliferated, but remained true to its nascent ethic: bring folks from the neighborhood together to have a good time. As 
the toddling culture gained its bearings, Hip-hop expanded upon its candid nature by becoming more comfortable discussing social ills. (Adkins 2001)

The Sugar Hill Gang released the first commercially viable rap record in 1979 with “Rapper's Delight,” and a year later Kurtis Blow's “The Breaks” scored the first goldselling rap single (Robinson 1999). Soon a multitude of artists were recording and producing hip-hop music. With a few notable exceptions like Grandmaster Flash, KRSOne and others, hip-hop remained essentially party and dance music throughout the 1980s. Messages of the everyday reality of ghetto life, drugs, guns, murder, etc. were rarely the topics of whole songs.

But in 1988, under the leadership of producer Andre (Dr. Dre) Young, a group called N.W.A. released "Straight Outta Compton," an album that spoke in explicit terms about ghetto street life and urban angst. No one had ever used profanity so extensively. No one had ever said so many derogatory things about so many different people at one time. The album had a Parental Advisory label before such warnings were mandated by the record industry. One track from the record, "Fuck The Police," caught the attention of the FBI, who opened a file on N.W.A. The group parted ways a couple of years later, with members O’ Shea (Ice Cube) Jackson and Eric (Eazy-E) Wright each releasing solo efforts to lukewarm responses by mainstream audiences. In 1992, Dr. Dre released his first solo album, "The Chronic," and it went multi-platinum, with a majority of the buyers being suburban, adolescent white children “who've deposed heavy metal and elevated hip-hop to the crown of Music Most Likely To Infuriate My Parents" (Chideya 1997). It 
was the mainstream breakthrough of the sub-genre of hip-hop known as "gangsta rap." Along with protégé Snoop Doggy Dogg, Dre related tales of drug dealing, gunplay, and misogyny over smoothed-out funk beats. Critics attacked the album as another example of what was wrong with the recording industry. Dr. Dre then produced a string of records by Los Angeles area rappers that kept this theme going, including Tupac Shakur, Snoop Dogg, Tha Dogg Pound, Kurupt, and most recently Eminem. Many others followed suit, and gangsta rap became the most popular type of hip-hop among buyers in the early and mid 1990s. These records repeated on the theme set by N.W.A.: bitches, hoes, drugs, guns, cars, money, and killing. Record companies encouraged the signing of such artists, caring little if what was being said or who was saying it had any basis in reality. This sub-genre created large profits for the record industry, and that was the bottom line. Gangsta rap “makes voyeuristic whites and naïve blacks think they're getting a slice of authentic ghetto life when in reality they're getting colorful exaggerations" (Dyson 1996). Just as Arnold Schwarzenegger is not in reality a Terminator robot, many gangsta rappers are in fact middle class kids looking to cash in on a trend. Attacks leveled at gangsta rappers by politicians and other forces assume that listeners take all of these images to heart, disregarding the ability of the listener to differentiate between fiction and reality. Such attacks on the genre get the media's attention though, with Tipper Gore and more recently Joe Lieberman getting ample coverage when they berate these artists.

While Tupac Shakur, Notorious B.I.G., and Eminem all have roots in the gangsta imagery created by N.W.A., Jazzy Jeff and the Fresh Prince, 2 Live Crew, and Lauryn Hill have all incorporated different approaches to the creation of their brand of hip-hop. 
Jazzy Jeff and the Fresh Prince, along with groups like Kid 'N' Play and Heavy D. and the Boyz, were a PG-version of hip-hop, avoiding curse words and telling stories about high school antics ("Parents Just Don't Understand") and summer lounging ("Summertime"). So when the recording Academy decided to give out the first rap/ hiphop award on February 22, 1989, the group was a good fit for the notoriously conservative Academy judges. The ensuing boycott of the event by Jazzy Jeff and the Fresh Prince and most other rap personalities removed whatever hope the Academy had of easing hip-hop into the fold, at least for that year.

The 2 Live Crew carved a niche in the mid and late 1980s in the often raunchy sounds of Miami "booty bass" music, which features pounding low bass frequencies and as the title implies, songs about booty ("Me So Horny," "Dirty Nursery Rhymes") . They took these themes and managed to gain limited nationwide recognition on their own independent label, Skyywalker Records. As their popularity grew, the sexually explicit content of their records garnered the attention of the Broward County, Fla. prosecuting attorney's office by way of an anti-pornography activist named Jack Thompson. Authorities pushed ahead with the case in March of 1990 and on June 6 of that year the group's album “As Nasty As They Wanna Be" was the first record to ever be found legally obscene. Record store owners who continued to sell the album in Broward County were subsequently arrested, as was the 2 Live Crew for performing material from the album at a show in Broward County days after the verdict.

Tupac Shakur began his recording career with the San Francisco area group Digital Underground in the late 1980s before releasing his first solo album "2Pacalypse 
Now" in 1991. He released four platinum selling albums between 1991 and 1995 before he was mortally wounded in a drive-by shooting in Las Vegas on September 7, 1996. He died from his injuries six days later.

Notorious B.I.G. came out of rapper/producer Puff Daddy's Bad Boy stable of artists, releasing his debut album "Ready to Die" in 1994. B.I.G. was considered one of rap's up-and-coming superstars, receiving lots of radio airplay while still maintaining his street credibility in the hip-hop community. On March 9, 1997, he was shot and killed in a drive-by shooting in Los Angeles just hours after attending the Soul Train Awards show. His second album, "Life After Death," was released just16 days after his death.

Lauryn Hill arose from the mid 1990s supergroup The Fugees, which also included Wyclef Jean and Praswell Ezekial. The group's focus was on intellectual lyrics and complex wordplay, and Hill became known as one of the best female rappers (and singers) on the hip-hop scene. When her 1999 debut "The Miseducation of Lauryn Hill" was released it was an instant success, incorporating both her rapping and singing abilities. On February 24, 1999, the recording Academy awarded Hill five Grammy awards for her work, including Album of the Year.

With the backing of rapper/producer Dr. Dre, Eminem burst onto the music scene in 1999 with his album “The Slim Shady LP.” His unusual style and lack of inhibition while on the microphone, coupled with his racial background (he is white), gained Eminem a rapid following. Controversy surrounded Eminem from the beginning of his career based on the graphic nature of some of his material. Songs like "Bonnie and Clyde '97" depict the artist killing his girlfriend (and mother of his child) and taking his 
daughter along for a ride to dump the body in a lake. His follow-up release, 2000's "The Marshall Mathers LP,” contained songs with similar subject matter. When the album went multi-platinum, it caught the attention of groups like the National Organization for Women (NOW) and the Gay and Lesbian Alliance Against Discrimination (GLAAD). So when "The Marshall Mathers LP” was nominated for Album of the Year by the recording Academy on January 4, 2001, these groups were outraged and began campaigns against Eminem. The nomination sparked a nation-wide debate about where artistic expression ends and hate speech begins.

Hip-hop's relevance to the young black community and to society in general is sometimes overlooked by those in the media not regularly associated with it. Hip-hop researcher Tricia Rose sees hip-hop music as a diverse and dynamic artform, calling it the central cultural vehicle for open social reflection on poverty, fear of adulthood, the desire for absent fathers, frustrations about black male sexism, female sexual desires, daily rituals of life as an unemployed teen hustler, safe sex, raw anger, violence, and childhood memories. It is also the home of innovative uses of style and language, hilariously funny carnivalesque and chitlin-circuit-inspired skits, and ribald storytelling. In short, (hip-hop) is black America's most dynamic contemporary popular cultural, intellectual and spiritual vessel. (1994)

Hip-hop music has become contemporary youth culture's most popular and most important outlet for creative expression and individuality. Media coverage of people involved in the hip-hop scene shapes the mainstream culture's vision of hip-hop and focuses it on particular occurrences. Coverage has steadily grown along with the culture, and this study is a critical analysis of national hip-hop coverage. 


\section{An Overview of Media Coverage of Hip-Hop}

Which hip-hop stories the mainstream media decide to cover and how they choose to cover them greatly affects how hip-hop and the personalities associated with it are perceived by the nation. When black artists and music are presented in the media, the trend seems to indicate that they are portrayed in stereotypical ways. Mainstream media coverage that focuses disproportionately on stories related to violent death, crime, and other socially corrupt behavior only add negative overtones to the limited mainstream awareness about hip-hop. These stories are many Americans only contact with the world of hip-hop, and opinions are often formed based on media exposure.

The media's negative coverage trickles down to parents, teachers, and other authority figures and casts a dark shadow on the music and musicians as a whole based on the actions of a few within the hip-hop world. Media consultant and speaker Neil Andersen sees lines being drawn between teachers and students concerning hip-hop music. He found that "many teachers reject hip-hop out of hand, without realizing its meaning or usefulness to teens" (1996). The negative gangsta imagery projected by a portion of the hip-hop world is being perceived by many as the only type of messages coming from this genre. Since hip-hop is primarily a youth-oriented genre, it is often viewed as dangerous by adults who see, hear, and read consistently bad press about it. Many hip-hop artists continue to assert that their work is getting a raw deal under the media microscope. San Francisco artist Rappin' 4-Tay accuses the media of intentional discrimination, saying "It's the media that don't go down to the 'hood that say what we 
rap about ain't what's going on. Rock acts like AC/DC can cuss all they want, and their crowds can slam dance and get all hurt, but nobody says anything” (Reynolds 1995). 4Tay is saying that white rock acts can get away with more in their songs than their black rap counterparts because the white group is more likely to be seen as stylized artists while the black group is perceived as an actual threat based on racist stereotyping.

Unfortunately for hip-hop artists who do not purvey violent or sexist imagery in their songs, these negative images sell records. Promoting a gangsta image helps perpetuate sales for gangsta artists, and controversial occurrences tend to get more press. Mentions of rap star Dr. Dre in the Los Angeles Times show up as often in the crime section as the entertainment page. Much more attention is given to his thuggish nature than his artistry (Gold 1993). Some in the alternative media have met one-sided portrayals of hip-hop artists with aggressive retaliation. Julian Shabazz, chairman of Awesome Records, harshly criticized the mainstream press, charging that several major newspapers, magazines and television networks have done very derogatory and sensational cover stories on rap. The intent of this is to give the public the misconception that their children are being poisoned by violent, uneducated, oversexed, out of control black rappers. These misrepresentations can only be interpreted as deliberate. (1997)

Parents and teachers who internalize the media coverage of stories such as the murder of Tupac Shakur or Notorious B.I.G. may see hip-hop as a divisive issue between themselves and their children/students based on such media focus. Parents don't want their children idolizing and imitating people they see as gang members and menaces to society. 
The mainstream press have acknowledged the widening popularity of hip-hop music. Although the majority of hip-hop musicians don't get large amounts of media coverage or mainstream radio play, artists have great selling power across the board. Hip-hop may have been expected to run its course and fall out of favor, but there is little argument that it has become one of the highest grossing forms of pop music (Forman 1995). Adolescents and young adults are the primary audience for hip-hop music, and they are less likely to buy a daily newspaper than someone in their 30s or 40s. Newspapers target their primary demographics first; music, art, and other forms of entertainment not seen as appealing to those demographics receive far less coverage than those that fit into the hegemonic framework.

\section{$\underline{\text { A History of American Black Music in the Media }}$}

Historically, black music in America has experienced questionable coverage from the media in other areas besides hip-hop. In a 1980 article for $\underline{\text { Crisis Magazine, social }}$ commentator Addison Gayle said black musicians have found that historically the white audience is "eager to accept the [black] cultural product, but not the practitioners. Thus Paul Whiteman is called the 'father of jazz,' Benny Goodman, the 'king of swing,' and Elvis Presley and the Beatles share equal billing as the architects of rhythm and blues" (1980). White imitators of black creations have been credited as the inventors in many cases, including the ones listed above. Artist Quincy Jones, a major contributor to the music business for more than fifty years, concurs with Gayle's commentary, noting 
"Black music has been down-played and historically considered low class music" (1995). Black musicians have been a driving force in American music since they were given mainstream exposure in the 1950s, and before that with blues and jazz dating back to the 1910s. Even today, coverage of the music is still not on par with coverage of music produced by whites in many mainstream publications. Since Soundscan, the tracking system of record sales, went in to effect in 1991, "there has been conclusive evidence that popular musical developments are not being accurately reflected in the mainstream media" (White 1997). One example of this is that Boyz II Men broke Elvis' charttopping record without even one cover story from a major music publication to honor the feat (White 1997). Many in the music media have strong personal preferences and favorite artists they wish to cover, and with these leanings comes an agenda of who and what is truly important in popular music. So, when an urban R\&B act like Boyz II Men broke a record held by an icon like Elvis, their sales record took a back seat in the eyes of the journalists, and thus in the eyes of popular audience.

Exclusion of minorities and minority viewpoints in the media has been examined and corroborated by researcher David Altheide, who found this type of exclusion in coverage of the Iran hostage crisis in the late 1970s: "The themes used in network reporting included statements and images that the government of Iran was irrational and irresponsible, a view not shared by Middle Eastern journalists" (1987). Viewpoints not in tune with mainstream hegemonic beliefs are generally considered irrelevant to a story unless they are an integral part of it. 


\section{RESEARCH QUESTION:}

What frames are the mass media presenting to society about hip-hop artists and culture through their coverage of the genre?

\section{METHODOLOGY:}

Six dates have been chosen to represent landmark events in the development of hip-hop in the mass media. I have collected stories published the day after Jazzy Jeff and the Fresh Prince were the first recipients of the Grammy for Best Rap/Hip-Hop Performance, the day of the 2 Live Crew obscenity verdict in Miami, the day after the death of both Tupac Shakur and Notorious B.I.G., the day after the 2000 Grammy Awards "Album of the Year" win by Lauryn Hill, and the day of the nomination of Eminem for four Grammy awards in 2001. Stories generated within one week of the designated days that represent a paper's initial coverage will also be included. These stories were chosen for their national prominence, thereby ensuring several independent stories written about each one. The Jazzy Jeff and Fresh Prince win marked the first time hip-hop music was recognized as a legitimate musical genre by the music industry. The obscenity trial of the 2 Live Crew put the overt and explicit lyrical content of some rap records in the national spotlight. The murder of Tupac Shakur brought the violence many rappers were talking about front and center in the American consciousness. Six months later, Notorious B.I.G.'s slaying made murder seem like a common occurrence in the hiphop community. The Grammy Album of the Year award to Lauryn Hill marked the first 
time a hip-hop-influenced record had achieved such popular recognition. Finally, the nomination of Eminem for Album of the Year once again sparked a national debate about the harsh lyrics being delivered on some hip-hop albums. This case was the first time such an explicit record had been recognized for its artistic value by the industry. Although Eminem is white, he has a great deal of credibility in the hip-hop world based on his association with Dr. Dre and his lyrical skills, and is therefore included in this study.

Using LEXIS/NEXIS and the WVU Libraries as search tools, I examined the New York Times, Washington Post, Miami Herald, Los Angeles Times, Chicago Sun-Times and USA Today as a representative sample of major newspapers covering a wide cross section of the country. All of these cities have burgeoning hip-hop scenes. These newspapers will be more likely to generate independent, non-AP copy stories. I examined the coverage of Rolling Stone and the Village Voice as a sample of alternative press coverage of the same events. Each story will be examined for recurrent frames.

There are practical limitations to this study. First, the issues of race and gender, though important aspects of this thesis and discussed throughout, are not the primary points of emphasis. Hip-hop is a black male dominated genre, but its widespread popularity has brought people of both sexes and many colors together under the umbrella of hip-hop music and culture. Although hip-hop cannot be discussed without including the topics of race and gender, these are not the factors that define hip-hop for the purposes of this study. Hip-hop was derived from mostly poor, inner-city neighborhoods with young people as the driving force behind it. It has since spread to every segment of 
society, regardless of race, gender, or social status. But the economic and social conditions that many hip-hop artists arise from ultimately puts them at odds with mainstream culture. Race and gender have everything to do with this separation as well, but the focus of this study is the dominant culture's representations of hip-hop culture, and this includes people of both sexes and various racial backgrounds.

Other practical limitations include the search facilities and timeframe of this project. I can only include material which appears in the LEXIS/NEXIS search engine. If any stories were present in any of these papers but excluded from the search results for any reason, they will be omitted. Also, the timeframe involved has forced me to choose only six newspapers from across the country. I have tried to examine the most representative papers available to compensate for lack of further diversity.

The following model of media framing is the primary tool used to interpret the findings of this study.

1. The sizing or importance of the report. "The essence of framing is sizing-magnifying or shrinking elements of the depicted reality to make them more or less salient." This allows assessment of the importance placed on the story by the newspapers. With this information, conclusions can be drawn about the relevance placed on each event by the media. These conclusions can be extended to draw conclusions about the mainstream culture's views based on media sizing .

2. The agency of a story must be considered. "Agency answers the question of exactly who did it-what casual force created the newsworthy act?” This allows an assessment of the placement of responsibility for the events under examination. Once 
responsibility for an event has been assigned by the reporter, conclusions can be drawn about how the reader interprets the event and those responsible for the event.

3. The identification factor in the story should be weighed. Are we encouraged or discouraged from identifying with people in the story? In reference to the KAL and Iran Air incidents, Entman says "the contrasting ways that victims were identified encodes and exemplifies the difference in discursive domains." This allows an assessment of the tone the reporter takes toward the people involved in the story. Identification sets the boundaries of "good" people and "bad" people in the story. These parameters can then be used to draw conclusions about the reader's perception of the people involved in the story based on their identification.

4. The categorization of the story determines how it is perceived. Is the story a crime story, human interest story, entertainment story, etc.,? "The discursive domain also inhered in the choice of labels for the incidents, which tended to place them in categories that conventionally either elicit or omit moral evaluation." This allows an assessment of the overall context of the story. If a story is categorized as an entertainment story, it may tend to carry less weight with the reader than a story categorized as a crime story because of the social relevance of the story. A story about murder is more likely to catch the reader's attention. It is a threatening story, it makes the reader feel like the world is a dangerous place, while a story about an awards ceremony carries less relevance to their daily lives. So a story about murder would elicit greater moral evaluation than a story about an awards ceremony. 
5. The generalizations, or "linking" elements of a story, must be examined. Does the reporter make connections to this story as being part of a continuing system of stories? Are there sweeping statements that draw broad conclusions about a whole instead of individuals? In the cases of the KAL and Iran Air incidents, Entman says "the moralizing frame in the KAL reports but not in the Iran Air coverage was also reinforced by the degree of generalization from the attacks to the nature of the two political systems." Reporters covering these two events tended to generalize the rhetoric about a plane attack to the entire Soviet Union, saying they suffered from "national paranoia." Generalization takes a single event and links it to another, usually larger, group of stories or events. This allows assessment of the story's connection to past events by the reporter. If a connection can be established, connotations from the past events add to the reader's knowledge base of a story and link the past stories to the one being examined. This can be used to draw conclusions about the reader's overall understanding of a story based on these linking elements. (Entman 1991)

These points represent the major areas of investigation used for this thesis.

In this study, identification is the most featured aspect of the model used for examination. The tone and word choice of the reporter is the most important element in determining how the subject of an article will be viewed by the reader. Identification is the reporter's way of telling the audience who to empathize with and who to disdain. This, more than any other criteria, determines how the reader will feel about the subject of a story. 
Also included in the results section are numerical counts of repetitious words dealing with the frame of each story, such as "violence" or "jail." Although these words are to be expected in a story about murder, the count is provided to illuminate the ideas and images that are consistently presented to the reader. Repetition of these words impacts the reader's impression of the subject matter through connotation. For example, when the words "arrest, jail, or prison" appear 22 times in the Tupac Shakur articles (Table 1), readers begin to associate Shakur with jail/arrest/prison more than they associate him with artistry or social influence, even when reading stories that deal with his music only. Thus, identification with Shakur as an artist with relevant social commentary is reduced because his arrest record is made more prominent by the reporter(s).

\section{RESULTS:}

Several trends in media coverage of hip-hop artists were discovered through this analysis. Frames of "controversy," "violence," and "jail/prison" appeared most often in these stories (Table 1) with $66 \%$ of stories appearing on the front page of their section (Table 2). This indicates that the reader's attention is most often drawn to these themes when hip-hop is involved in a national news story. Such coverage associates all hip-hop artists and culture with these themes and portrays them in a negative light. 


\section{FINDINGS FOR GRAMMY WIN OF JAZZY JEFF AND THE FRESH PRINCE:}

Coverage of Jazzy Jeff and the Fresh Prince's win for the first Grammy in the rap/hip-hop category in 1989 tended to focus on the boycott of the event by many rap artists who felt slighted by the lack of broadcast coverage for the award. Except for Kool Moe Dee presenting the R\&B award, no hip-hoppers showed up as a symbol of protest.

The overall sizing of the articles was small. The Los Angeles Times is the only paper to put this story in its A section, appearing on page 28 . The others that reported the event(the Chicago and Miami papers didn't cover the story at all) put it in the C and D sections, with none of these stories totaling more than 1,000 words. This placement illustrates the relative lack of importance given to this story by the newspapers

Agency for the boycott is not placed directly on Jazzy Jeff and Fresh Prince but on the hip-hop community as a whole. "The only real controversy surrounding the Grammys this year was the boycott generated by some of the rap acts to protest the fact that the new rap award was not included in the televised ceremonies" (Hunt and Hochman 1989). Hip-hop is unsatisfied with the Academy's creation of the rap award if televised recognition is not accompanying the award.

Identification with the artists is mixed across these stories. The word "boycott" appeared in two of the four stories, surfacing three times in the Los Angeles Times story (Hunt and Hochman 1989). Boycotting was a tactic utilized by many black leaders in the past and the repeated use of the word by the Times carries connotations of past public protest by black people. Stressing the fact that rap artists boycotted connotes images of the Civil Rights Movement, something that many hegemonic whites may see as negative. 
The Los Angeles Times also called the protest a "controversy," while the Washington Post appeared to side with the protesters, citing "critics (who) said that without television exposure, the rap award was mere tokenism" (Harrington 1989). The New York Times called the hip-hop and heavy metal categories the "invasion of the great unwashed to the pop professionals who choose Grammy winners," implying the artists are lower class or out-of-the-ordinary (Parales 1989). Calling these artists "the great unwashed" may have been written in jest, but heaping all the artists involved into a sub-standard pile generalizes them as the "other" and discourages identification with these artists.

This story is categorized as part of an entertainment story focusing on the Grammy awards. It is relegated to more obscure section of the papers and is portrayed as a story of significance.

No generalizations linking hip-hop to any other continuous system of stories are overtly present, although the term "boycott" does have Civil Rights connotations as mentioned earlier in this section.

\section{FINDINGS FOR OBSCENITY TRIAL OF 2 LIVE CREW:}

Newspaper coverage of the 2 Live Crew obscenity case varied greatly from region to region. It is generally considered an important story by the media for the implications on censorship law.

The sizing of this story reflects the social importance of a court ruling on the hazy area of censorship law. The Washington Post put it on the front page, giving the story a 
750 word write-up. USA Today also put the story on the front page, although it waited until four days after the verdict to do so, perhaps waiting to see if any record store owners or the group would be arrested for selling the banned material(which they were). USA Today also carried a separate story in the Life section of the paper on the effect the verdict will have on the recording industry. The New York Times relegated the story to page 22 of the D section, and the Los Angeles Times placed it on the first page of the F section under the "Entertainment Desk" label and gave the story a 1,000 word article. Within the five stories, variations of the word "arrest" (arrests, arrested) appeared 14 times, and variations of the word "controversy" (controversial) appeared six times.

Agency for this event is placed on the 2 Live Crew for producing obscene material. They are responsible for making a record so foul it is illegal to distribute. "“As Nasty As They Wanna Be' is the first recording in the history of popular music to be deemed obscene," singling out the 2 Live Crew as the only group to ever cross the ambiguous threshold of obscenity (Philips 1990).

Readers are not encouraged to identify with the Crew or their plight; a group member is only quoted once in the five stories compared to numerous quotes from the judge and prosecuting attorneys. The focus of most of the stories was the arrest of store owners and the group members themselves for selling obscene material and the comments of the judge in rendering the decision. A quote from the judge used in more than one article concerning the Crew's music gave credence to the prosecution: "It cannot be reasonably argued that the violence, perversion, abuse of women, graphic depictions of all forms of sexual conduct, and microscopic descriptions of human 
genitalia contained on this recording are comedic art" (Philips 1990, Parker 1990). This statement comes from a man in a position of high authority, condemning the record and group as repugnant and obscene. This holds the group (and by implication the whole rap/hip-hop community) responsible for producing material so foul it cannot be sold to the public. The judge is also quoted in two separate articles as saying the album "is an appeal to 'dirty' thoughts and the loins, not to the intellect and the mind" (Parker 1990, AP 1990). The question that loomed heavily over this case was: "Why had a black rap group been singled out for an obscenity prosecution--particularly in a county in which strip shows, adult reading material, and pornographic videos are readily accessible to consenting adults?" (Gilmore and Karl 1990). This issue was not addressed by any of the reporters who covered the trial. "Federal Judge Finds Rap LP Obscene" was the only story the Washington Post ran on the subject the day of the verdict (Parker 1990). Group member Luther Campbell pointed this out in the Los Angeles Times article, saying 'You've got Guns 'N' Roses and Andrew Dice Clay sitting next to my album on the record shelves in these stores. Why is my record obscene and their's isn't? There is no way anyone can tell me that they are not singling us out" (Philips 1990). Three black men making graphic sexual references on record is considered more offensive by county prosecutors than a white man (Andrew Dice Clay) making similar remarks.

This is categorized as a crime/legal issues story. This is evident by the repeated quoting of the judge and lawyers in the case and the focus on the legal issues involved. Such a categorization places these hip-hop artists as criminals guilty of producing 
perverse musical works. This falls into the realm of stereotype, casting the members of 2 Live Crew as overly sexual black males.

No generalizing statements were present linking this story to other systems of stories.

\section{FINDINGS FOR MURDER OF TUPAC SHAKUR:}

Coverage of Tupac Shakur's murder, beyond the descriptions of the scene and events surrounding the shooting, focused on Shakur's past and his apparent contradictory nature.

Sizing of the eight stories covering the death made this the most important of the stories under examination. The story received $1 \mathrm{~A}$ placement in all of the papers, except for columns which were placed in the Living sections. This is the cue to the reader that this is an important story, and it is part of the national dialogue of the day. This story has relevance in the debates over violence in rap lyrics, gun control, gang problems, and Shakur's death is fuel for these issues. Variations of the word "violence" (violent) appear 26 times, "jail/prison/penitentiary" appears 15 times, "arrest" appears seven times, and “controversy" four times.

Agency for the murder is shifted away from the perpetrator and back to Shakur on occasion. The listing of his criminal record as part of the story implies that his murder was due to his deviant lifestyle (Gundersen, Haring and Oldenburg 1996, Pitts 1996, Constable 1996). He was "another violent rapper glorifying gangsta culture in his music-living by the lyrics, dying by the lyrics, getting what he deserved" (Gundersen, 
Haring and Oldenburg 1996). When the reporter crafts the story in this way, Shakur assumes responsibility for his own death because he chose to break society's rules and paid the ultimate price.

Readers are not encouraged to identify with Shakur. Reporters invariably point out his criminal record and his sometimes violent lyrics to point to the conclusion that his lifestyle led to a murderous end. Coverage of Shakur's death, more than any other examined in this study, returns again and again to themes of violence and jailtime for Tupac himself or those associated with him. The fact that "His mother, Afeni Shakur, was a member of the Black Panther Party and spent part of the time she was pregnant with him in prison" came up in a majority of the stories (Hilburn and Crowe 1996). His police record, including acquittals, were printed in a majority of the stories as well. His death put the perils of going from an inner-city youth with a sordid past to an international music superstar in the headlines. This story was used to sum up the feelings that many have about hip-hop music: it is violent, and it begets violence. "Tupac Shakur, 25, Rap Artist Who Personified Violence" was the New York Times headline the day he died (Parales 1996). The story did acknowledge Shakur's socially conscious lyrics and acting roles along with his rap sheet. Although the media tended to cover this story from the "he's an angel, he's a devil" angle, what was missing was the larger context. As Jill Nelson explains:

It's not enough to quote a few lyrics. Or tell us that his mother, Afeni Shakur...was pregnant with him while she was incarcerated. Or that he grew up fatherless. Outside the context of what it means to be young, black, poor and male in America, these facts reveal little. They do not begin to explain the depth of Shakur's pain, rage, and self-destructiveness. 
To suggest they do is to reduce his life and the lives of thousands of young black men whose existence he reflected and articulated to stereotype. (Nelson 1996)

The mainstream media represent a bad boy, living on the edge and ultimately getting what he asked for.

This is categorized as a crime story with the focus on the shooting, but Shakur is portrayed as much as a criminal as is the killer in some instances by emphasizing his criminal record. This casts hip-hop artists as violent thugs, living in a world of unbridled aggression and lawlessness.

The major generalization in the series of stories is the linking of Shakur with Dan Quayle's call to remove his “2Pacalypse Now” album from stores in 1992 after a Texas police officer was killed by a teenager who had listened to the record (AP 1996). This again puts Shakur at odds with mainstream culture, casting him as an inflammatory artist who incites young people to kill police. The context of the song that allegedly caused this boy to shoot the officer is not mentioned in the article. There are no generalizations linking Shakur to other more positive aspects of his recordings.

\section{FINDINGS FOR MURDER OF NOTORIOUS B.I.G.:}

Media framing of Christopher Wallace's (Notorious B.I.G.) murder heavily emphasized the alleged rivalry between Wallace and Tupac Shakur.

Sizing for these stories casts the event as important in the eyes of society. The story made the A section of every paper that reported on it, although the placement 
ranged from the front page of the Miami Herald, Washington Post, and Los Angeles Times to page 10 in the New York Times. Readers are made to feel this is an important story; it received front page headlines in a majority of the markets and a column in the Miami Herald.

Agency for the murder is placed mainly on Wallace for glorifying the image of a gangsta. In the New York Times, Wallace is called "a gangsta rap artist who turned his drug-dealing past on the streets of Brooklyn into a platinum-selling recording career" (Purdam 1997). The Chicago Sun-Times refers to him as a "rap star," avoiding the trend of vilifying Wallace. The Sun-Times quoted the police as saying they "had no leads and that there is no indication of a tie between the attack on Wallace and the Sept. 7 killing of Tupac Shakur," although they did chronicle past run-ins between the two (Waxman and Iverem 1997).

Identification with Wallace is not encouraged; he is framed as a hoodlum who managed to pull himself out of poverty by glorifying criminality. "He put a New York stamp on gangsta rap, relying on his street credentials as a former drug dealer and street hustler in the rough Bedford-Stuyvesant section of Brooklyn" (Waxman and Iverem 1997). Although he is a success story in the literal sense, negative framing of his past discourages identification with Wallace. Six stories covered the shooting, and variation of the terms "feud" or "rivalry" appears nine times, and "East Coast" and/or "West Coast" (in capital letters) or "bicoastal" appears 12 times. Examples of coastal tension rhetoric include "Wallace and Shakur were rivals, with Shakur representing West Coast gangsta rap and the Brooklyn-born Wallace a leader of the East Coast hip-hop scene" 
(Waxman and Iverem 1997) and "The shooting raises serious concerns about an ongoing war between East Coast and West Coast rappers" (Waxman and Iverem 1997). Speculation linking Bad Boy Entertainment and friends of Shakur to the killing appeared in a majority of the stories. USA Today was the only paper not to cover the story, downplaying the relevance of Wallace and of hip-hop music to the larger culture.

This story is categorized as a crime story, with the focus divided between the events surrounding the murder and Wallace's background as artist and former drugdealer.

The audience is encouraged to generalize this story as part of a continuing saga, as a "Part 2" of the Shakur murder. Shakur's slaying was mentioned in every article, and most gave the impression that the two were related in some way, as indicated in the headline "Rapper is Shot in Echo of Killing Six Months Ago" (Purdam 1997). The echo reference insinuates that the second murder is closely related to the first, just as an echo is a reaction to an initial sound.

\section{FINDINGS FOR COMBINED MURDER COVERAGE:}

Stories presented by the nation's major newspapers show signs of hegemonic framing surrounding these two murders. Media framing portrays the two as ultimately getting what they deserved for living and rapping about a dangerous lifestyle. Some examples of this framing include the following: "Tupac Shakur, the rapper whose raw lyrics drew on the rage of a coarse urban existence and seemed a blueprint for his own violent life, died Friday from wounds suffered in a drive-by shooting” (AP 1996), and 
"Wallace intensified the emphasis on machismo in New York rap into a focus on criminal life, rapping about robbing and killing, and about how much conditions had deteriorated in his neighborhood during his lifetime" (Waxman and Iverem 1997). Music publications like the Village Voice and Rolling Stone, which covered these two men much more frequently than any newspaper, often did not share the hegemonic view of Shakur or B.I.G.

Sideliners will suggest...he 'had it coming' or 'chose that lifestyle.' I believe that for Pac, living intensely was never an option. We were born the same year and poor and came of age in the most violent era our people have known. Pac didn't have a death wish so much as an understanding (and with it an eerie peace) that life would be short. (Hampton 1996)

This excerpt, written by a man much closer to Shakur in terms of age, race and economic status, did not conclude that Shakur was "asking for it." Rather he felt that the conditions Shakur grew up in forced him to confront the fact that life for a poor black man in America would be harsh and brief. This is the basis for much of the lyrical content on his albums.

Examples of generalizations linking the two are the New York Times calling Wallace a "fierce rival of Tupac Shakur" and that "Mr. Shakur had accused Mr. Wallace of involvement in a 1994 robbery in which Mr. Shakur was shot and lost \$40,000 in jewelry" (Purdam 1997). Also, the Los Angeles Times says “(detectives) are investigating whether Wallace's death is linked to bicoastal tensions within the rap world" (Lichtblau, Philips and Coker 1997). Four years after the death of Notorious B.I.G., there is still 
nothing connecting the murders other than their rap star status and a "war of words" the two had.

The framing of Shakur and Wallace as part of rival black "gangs" (i.e. their record labels Bad Boy and Death Row) vying for control of the music industry (instead of a street corner) was another popular frame that disregarded the lack of factual evidence linking the two murders. "Rapper is Shot to Death in Echo of Killing 6 Months Ago" read the New York Times headline the day of Wallace's death. The journalist goes beyond covering the story at hand and reports on the "speculation inevitably center(ing) on the rivalry between Mr. Wallace and his producer and protector, Sean (Puffy) Combs of Bad Boy Entertainment and Mr. Shakur and his producer, Marion (Suge) Knight of Death Row Records." From the media coverage of Wallace's death, along with Shakur's, the layperson may believe that the hip-hop community is nothing but violent thugs with homicidal messages spilling over to its listeners (which are now more than ever young, white suburban adolescents).

\section{FINDINGS FOR LAURYN HILL'S GRAMMY WINS:}

In contrast to the other five stories, Lauryn Hill's Grammy wins in 1999, including "Album of the Year" honors, gave hip-hop its most positive coverage to date.

Different markets varied considerably in their sizing assignment to the story. The story's placement ranged from front page headline (Miami Herald and Los Angeles Times) to the D "Life" section (USA Today). The stories mainly focused on the dominance of women at the event. 
The agency of this story places Hill as a purveyor of "good" hip-hop, an exception to the negative messages that hip-hop usually presents. In fact, the Miami Herald called her the "new face of hip-hop" (Cobo-Hanlon 1999). What the reader takes from these stories is that hip-hop, if crafted in a mild and accessible way, is acceptable to the elite, mostly white members of the Academy, and thereby acceptable to mainstream culture. As a corollary to this premise, explicit songs about street life, poor neighborhoods, and social strife, will not be recognized as top-notch music by the mainstream culture.

Interestingly, Hill's album did not win the Rap/Hip-Hop Album of the Year. That prize went to Jay-Z, who did not attend because the award was (again) not televised. The Los Angeles Times quoted a spokesman for Jay-Z as saying "The omission was 'disrespectful' to rap," especially considering it accounts for 10 percent of all record sales (Boucher 1999). Jay-Z asked that his name be withdrawn from the running, but he ultimately won the award anyway. The New York Times reported Jay-Z was "boycotting" the ceremony because the Academy is "paying more attention to violence in rap than to his upcoming tour" (Strauss 1999). Will Smith (Fresh Prince), who boycotted the event 10 years earlier because the rap/hip-hop award did not receive a televised presentation, won for Best Rap Performance, and this was the only hip-hop award that was televised. Unlike Will Smith or Lauryn Hill, Jay-Z represents the harder-edged side of hip-hop, and he was excluded from national broadcast coverage of his win. Only the softer and more accessible artists were given a forum to speak to the nation, suggesting to the hip-hop community that artists who produce explicit material will not get mainstream recognition by the Academy. 
Readers are encouraged to identify with Hill, who brings a gentler persona to what has been viewed as "bad boy" music. She is accessible, friendly, a woman, and a hip-hop artist. These features defy the conventions of what hip-hop is supposed to be. During her acceptance speech, she "read a passage from the Bible" and "thanked her children for, among other things, "not spilling anything on mommy's dress"” (Cobo-Hanlon 1999). These images contradict the previous depictions of hip-hop as unsophisticated and violent. We are told that her music and personality are acceptable to a mass audience, and this is seen as unusual for hip-hop. Hill's five wins surpassed Carole King's record for most Grammys won by a woman in a single night, and this was the first time a hiphop album had won the event's top honor. The writers were aware of hip-hop's past negative media publicity; the Los Angeles Times ran a column with the title, "Hip-Hop: No Bad Rap Anymore” (Hilburn 1999). Hill is most often quoted as saying "This is crazy, 'cause this is hip-hop music, you know what I mean?" (Cobo-Hanlon 1999, Harrington 1999, Strauss 1999, Boucher 1999, Hilburn 1999). This quote points out the anomaly of the music getting positive recognition in the mainstream press and culture. Hill is shocked to win so many awards for a hip-hop album. The Los Angeles Times column said she had "the accessability of Stevie Wonder," separating her from the harderedged elements usually associated with hip-hop and linking her to a black artist widely accepted by the white community (Hilburn 1999). She is also a woman, eliminating the "angry-young-black-male" stereotype from the coverage. Although her album was embraced in the hip-hop community as a brilliant work, it was not purely a hip-hop 
record. She sings, not raps, on more than half the songs on the album. This was never brought up in the media coverage of the ceremony.

The story is categorized as part of an entertainment piece. Hill is never the focus of an entire story but a highlight of the Grammy Awards as a whole.

No linking generalizations were found in this group of stories except for the article connecting her to Stevie Wonder. This places her squarely in the mainstream, since Stevie Wonder has had several crossover hits throughout his career.

\section{FINDINGS FOR EMINEM'S GRAMMY NOMINATION:}

Eminem's nomination for Album of the Year in 2000 created a national debate over the content of his music and the line between hate speech and art.

The sizing of this story varied according to region. The Miami Herald and Los Angeles Times put this story on the front page, emphasizing the importance of this nomination to the national dialogue over explicit lyrics in rap music. The other papers relegated this story to the C, D, and E sections, in the "Entertainment," "Arts," "Style," "Life," and "Features" categories. The Los Angeles Times also featured two columns on the year's nominations, with one staunchly in favor of Eminem winning the award. The author calls his album "the only rap collection that deserves its place on the ballot" (Hilburn 2001). Within the articles, variations of the word "controversy" appeared five times in eight articles, "violence" appeared seven times, and"shocking" appeared three times in a single Los Angeles Times front page article. Reporters felt comfortable 
employing myriad adjectives to describe Eminem's album, from "slasher film fantasy" in the Chicago Sun-Times to "potty-mouthed" and "naughty" in the Washington Post.

Agency in this story is placed on Eminem. He is responsible for producing a controversial (i.e. misogynist, violent, gay-bashing) album, and the nomination represents his album as the best hip-hop had to offer in 2000 .

Readers are not encouraged to identify with Eminem or his music, and since his album is nominated as the best hip-hop had to offer in 2000, hip-hop is again placed in a negative, controversy-filled light. National Academy of Recording Arts and Sciences (NARAS) president Michael Greene is the most quoted figure in the stories, defending the nomination as a recognition of excellent lyrical skill, not an endorsement of lyrical content. His quotes include statements such as, "I hope the public realizes that by recognizing the album, we're not honoring the subject matter" (Gundersen 2001) and "You've really got to view this in the context of art being a pretty extreme medium sometimes" (Cohen 2001). Greene's comments are defensive, which shows that hip-hop is out-of-line with mainstream values and culture. The New York Times is the only paper not to call attention to the controversy surrounding Eminem's nomination, reporting strictly on the nominees and the voting process.

This is categorized as an entertainment story revolving around the annual Grammy awards. As an entertainment story, it is considered lighter by the audience than a crime story, although the controversial nature of Eminem's album gives the story greater social relevance in the debate about free speech. Eminem's album is described with 
generally negative adjectives like "naughty" and "misogynist," again casting hip-hop artists as crude and cojntrary to mainstream values.

There were no generalizations linking this story to past events.

\section{OVERALL FINDINGS:}

The Los Angeles Times and Miami Herald were the two papers most likely to place coverage of these stories on their front page. Other than the 2 Live Crew verdict, the LA Times put every story under examination on the front page. This may be explained by the fact that the Grammys are held in Los Angeles, and news of Grammy winners is considered more important there than elsewhere in the country. Also, Notorious B.I.G. was murdered in Los Angeles, so the local nature of the story put it in a higher status than in other places. Placement of the stories is vital to understand the total impact of the media's message of importance in relation to these stories (Table 2). Story placement on the front page of any section makes it more likely to be read. Unlike television news, where "every item is akin to a front page story," stories buried in a section "conveys a message that the events lack urgency and social importance" (Entman 2000). The most significant finding is that $78 \%$ of crime-related stories made the front page of their section as compared to $56 \%$ of the non-crime-related stories. The social importance of these criminal events involving hip-hop artists is perceived as much higher than the artistic achievements of hip-hop artists. Furthermore, the articles in the noncrime-related categories rarely focus entirely on the artist, but on the Grammys as a 
whole. The coverage is less in-depth due to the constraints of the reporter's assignment to cover the entire ceremony, not just the nominees or winners.

Seventeen reports $(47 \%)$ received placement in the A section, but 10 of those were from the crime-related stories. Greater importance is placed on the stories involving criminal activities. Two of these A placements were columns based on the original story, giving reporters free rein to voice their opinions. These opinions generally do not favor the artists or the hip-hop community. C and D sections were the next most popular section, accounting for another 10 stories $(28 \%)$.

The sources cited by these articles play an integral role in how the audience perceives the information. Of the 36 stories reviewed, six were columns, which do not conform to the necessary story type for source coding analyzation, and were therefore omitted from the source coding table. Sourcing in a column format is not intended to meet the "fair and balanced" criteria of a regular news report. Eight key sources were identified and coded by their frequency of use in the remaining 30 stories (Table 3 ). The most frequent sources in these stories are the artists themselves or other musical artists who are represented in $47 \%$ of the applicable stories. The second most popular sources were industry analysts and/or activists, occurring in $30 \%$ of the reports. Authority figures, such as judges, sheriffs, and prosecutors tied for third most popular with quoted lyrics from the artists albums, both utilized in $23 \%$ of the stories. Friends and fans appeared in $20 \%$ of the stories, followed by lawyers for the artist at $13 \%$ and record store owners and eye witnesses to an event each cited in $10 \%$ of the stories. The previous tabulation represents only the number of stories that used these sources at least once, not 
the frequency of use within the story. The stories that utilized authority figures as sources (mostly crime stories) used them several times within the same article, reinforcing them as the central and most important sources for the report. The artists themselves or lawyers representing them are quoted less frequently within these articles, encouraging the reader to identify with the authority figure and perceive them as the most important source in the story. The artists are relegated in terms of importance by the lower number of quotes, and the reader is not encouraged to identify with them on the same level as the authorities.

Since three of the stories are crime-related and three are award-related, it is necessary to separate them into two categories for further analysis (Table 4). Within the 18 crime-related stories (2 Live Crew, Tupac Shakur and Notorious B.I.G.), authority figures are quoted 15 times compared to a total of 13 times for artists and their attorneys combined. Obviously neither Shakur nor B.I.G. could comment on their own death, but each was quoted from earlier interviews with various magazines and newspapers. Most of these stories made multiple use of quotations by the same authority figure and included more than one authority figure in the story. Comparably less use of multiple quotes by one or more artists or artists' lawyers is present. This informs the audience that the authority figures are the most important sources in the story, allotting them the most space and the most frequent amount of multiple citation. In the end, reporters relied on authority figures to provide the substantial amount of information for these stories, relying on the artists involved and their legal representatives mainly for reaction to these authorities. 
The overall length of the stories involved reveals the importance of hip-hop to major newspapers, and in turn to society (Table 5). The sizing or importance of these events gives the reader a sense of the relevance of the story. The word-count category most often found was 500-999 words. Of the 36 stories examined, 29 were less than 1,500 words, and of the seven that were more than 1,500 words, four contained lists of all the Grammy winners or nominees. Such stories did not focus on the hip-hop artist alone but on the Grammys as a whole, greatly limiting what was said about the artist(s).

Average story length differs greatly between newspapers, and this must be taken into account when evaluating these word counts. USA Today gives very few stories coverage of great length, while the Washington Post is known for articles stretching to over 5,000 words or more. This information is provided simply as a reflection of the coverage these particular stories received within the newspapers examined.

\section{FINDINGS FOR COLUMNS:}

Five of the six column pieces published concerning these events focused on the two murders. Four aimed at Shakur's death and the ramifications of it. USA Today included a 1,343 word article about the contradictory nature of Tupac and his music. He was "lauded for his lyrics about education, pride and black self-sufficiency, but at the same time was widely criticized for denigrating women and promoting violence" (Gundersen, Haring, and Oldenburg 1996). The author compares the personal responsibility that Shakur shoulders for projecting gangsta imagery with the responsibility of society to educate young people in an examination of the plight so many urban youth 
face. Shakur's background and his mother's jail time are mentioned, and a list of his criminal record ends the piece. It doesn't seem to encourage or discourage identification with Shakur, citing both positive and negative aspects of his life. The Miami Herald's 783 word column rips Shakur, his lifestyle, and his music. The author describes Shakur as having "the devil's own smile" and his new album as a "wisdom-free, expletive-laced, scrap of malignancy" (Pitts 1996). He says pop culture has embraced death, and young people are searching for a "new promise" of faith that their parent's music had. The author sees gangsta rap as a curse on this generation. The Washington Post featured an 866 word column that comes from a black mother of a teenaged girl. She learned about gangsta rappers through her daughter, and struggles to understand the attraction. She believes gangsta rap consists of blacks going for each other's throats instead of taking on the system that created the conditions that gangsta rap addresses. She closes by acknowledging the duel personality of Tupac as both gangsta rapper and son of a Black Panther. The final Tupac article is short 203 word piece from the Chicago Sun-Times that points out the choices Shakur had, and claims that the "Thug Life" he chose ultimately led to his own demise. None of the articles encourages identification with Shakur. He is at best a victim of his upbringing and at worst a violent misogynist who had the chance to change and blew it.

Notorious B.I.G. received one column piece from the Miami Herald that angrily “damn(s) Christopher Wallace and every other gangsta rapper who sold that soul-killing lie" of the gangsta lifestyle (Pitts 1997). The author notes that violence is present in all forms of music from Frank Sinatra to Guns 'N' Roses, but gangsta rap has taken it "too 
far." His death is ultimately "a reflection of the 'art' he made," and young black and brown children will now look up to Wallace and Shakur as icons. Identification with Wallace is definitely not encouraged. His music is part of the problem, not part of the solution in the author's eyes.

Lauryn Hill gets the lone positive column. The Los Angeles Times calls her one of the "biggest winners" of the evening and a sign of hip hop's acceptance in mainstream culture. She is dubbed the "ambassador of hip-hop," introducing it to the average pop listener (Hilburn 1999).

After examining the framing of these six events, the most common frame surrounding hip-hop is controversy. Five of the six events had some mention of controversy or friction between hip-hoppers themselves or with the mainstream culture. This is a cue to the public that the hip-hop community is rebellious and uncooperative, a negative influence on society and on our children. "They" are not like "us."

Lauryn Hill is the lone contrast to these images. She represents the softer side of hip-hop, a woman who is accessible and, most importantly, non-threatening to the dominant culture. She revived the sound of black music from the Mo-town era and incorporated it into modern hip-hop, a kind of R\&B/hip-hop hybrid. Her album made it OK for mainstream listeners to like hip-hop, but in doing so, she is put in the position of the token hip-hop celebrity of the moment. Hill is seen as the exception to the rule, a rapper with respect and dignity in a quagmire of filth and thuggery. The positive influence she may have on the average reader is more than offset by the large amount of negative press that hip-hop has received. 


\section{FINDINGS OF ALTERNATIVE PRESS COVERAGE:}

In order to give some perspective on how the mainstream media covered these events, I examined coverage in Rolling Stone and the Village Voice as well. These two publications represent American music and youth culture with an ear to the street, looking

for new trends and youth market appeal. The most noticeable feature of the differences in coverage across all the stories was the lean toward the musicians in Rolling Stone and the Village Voice and the lean against them in major newspapers (with Lauryn Hill the noted exception). Hip-hoppers were much more likely to be viewed in a favorable or empathetic light by the music publications than by the newspapers. It may appear obvious that a music-oriented magazine would be more supportive of musicians than the mainstream media, but most of the stories go beyond the artists themselves. Greater social issues of race, class, censorship, and such are all incorporated in these stories. There was no guarantee that the artists would be seen in a sympathetic eye by the magazines and not by the newspapers. But time and again that is how it turned out. These trends point to the larger issue that this study attempts to flush out: society looks to the media to report "the truth," yet stories in the media show real signs of subjectivity in relation to the form of black music.

Rolling Stone's coverage of the Jazzy Jeff and Fresh Prince Grammy ceremony included a portion dedicated to the Rap/Hip-Hop award. The Academy's decision to give the Rap/Hip-Hop award to Jazzy Jeff and the Fresh Prince is chastised, calling the group the "mainstream choice" for the Grammy win (Handelman 1989). The article mentions 
the rap boycott of the event and gives NARAS president Michael Greene the opportunity to address it. No hip-hop artists were consulted for the article. This lack of contact with the protesters downplays the importance of the boycott. Greene says every year brings upset groups who do not make it on the air, implying that hip-hoppers are wasting their time with such an action. Readers are not encouraged to identify with the boycotters as the lack of sourcing suggests. The Village Voice only provided a list of winners from the ceremony, and no special mention of the Rap/Hip-Hop award is present.

Rolling Stone's coverage of the 2 Live Crew trial produced four separate articles. Two are against the ruling; the first calls into account the age and race-based nature of the ruling and the other is a list of artist responses to the ruling in which every respondent comes out against the verdict. The other two articles are more objective in tone. The first puts the case in historical context, citing the arrest and prosecution of Lenny Bruce, The Doors, the Dead Kennedys, and the Rolling Stones on obscenity charges. It examines national anti-obscenity cases and gives details of the Crew's legal hearing while chronicling the arrest of record store owners who sold the album after the ruling.

The Village Voice's coverage includes one article entitled "How to Rap Dirty and Influence People" with selected lyrics from the obscene album and reports on the arrests of the 2 Live Crew and record shop owners who sold the album. The title is an acknowledgment of the greater record sales the Crew would have after this ruling. It includes an interview with Charles Freeman, a store owner arrested for selling the album. No quotes from the judge or prosecutor were included. Both publications featured more anti-censorship rhetoric than the major dailies, noting the likely increase in album sales 
from the publicity and the hypocrisy of the ruling in strip club-laden south Florida. Readers are again encouraged to empathize with the Crew, seeing them more as victims more than criminals.

Rolling Stone's coverage of Tupac Shakur's murder featured one article entitled "Easy Target" that discusses the brilliance of Shakur and his music, calling him as relevant as Kurt Cobain, and offers some reasons for his harsh lyrics. His albums and their contents are analyzed. Readers are encouraged by the language of the piece to identify with Shakur and his troubled life. The article is a commentary on American culture with Shakur representing the poverty-stricken underclass. The author speculates that his death will "be justification for yet another campaign against hardcore rap and troublesome lyrics" (Gilmore 1996). Shakur's legal troubles are seen in the context of his upbringing and social status.

The Village Voice featured four separate articles on Shakur with varying opinions on his personal responsibility for his own demise. The first article opens with a metaphor of Shakur as "the wind" with the capacity to "change and destroy" (Hampton 1996). The author suggests Death Row Records chief Marion "Suge” Knight bears much of the responsibility for planting “conspiracy tales" in Shakur's mind while Shakur was serving a jail sentence. Knight is accused of fabricating stories about Notorious B.I.G., thus beginning the "rivalry" between the two. The author then reminisces about personal encounters with Shakur. Article two argues that Shakur's death was his own fate. Shakur "seemed to treasure his criminal-minded companions," continually putting himself in harm's way by associating with violent people (George 1996). The author is 
both saddened and angered by the death, particularly because Shakur possessed so much talent. Article three addressees the "live by the gun, die by the gun" mentality coming from the media and elsewhere. The author questions MTV's coverage of the death, citing the fact that Kurt Cobain's death from a self-inflicted gunshot wound received a whole weekend of memorials while Shakur's death received "a news report and four videos played in his honor" (Stovall 1996). The article asserts that such Shakur's selfdestructive behaviors, once learned, are difficult to resist. Article four compares the hiphop community to a high school, where the fantasy of indestructibility leads people to do stupid things. The author sees the rage of men like Shakur stemming through generations, each one taking themselves more seriously and "snarl[ing] at our parents and grandparents for laughing" (Toure 1996). He suggests we must learn to laugh again. All of the authors are allowed to run with their gut feelings about the story, espousing whatever perspectives they feel are important and relevant.

Rolling Stone's coverage of Notorious B.I.G.'s murder was held to a single article chronicling the shooting, a background of Wallace's life, and the tensions between Wallace and Tupac Shakur. The article says Wallace had no problems with Shakur and that the East Coast/ West Coast rivalry was over after Shakur's death.

In identical fashion to coverage of Tupac Shakur, the Village Voice dedicated four articles dedicated to Notorious B.I.G. The first addresses the rivalry between Wallace and Shakur and gives a history of the alleged feud. Eyewitness Kevin Kim, a close friend to Wallace, is cited throughout the article for his perspective on the shooting and the events leading up to it. The possibility of connections to LA gangs is mentioned, quoting 
a Crip member as saying "This is a hit, there will be more" (Anson 1997). Article two is written by Source editor-in-chief Selwyn Hinds, who was in a car just five or six behind the one Wallace was riding in when he was shot. He describes the scene and his reactions to it, then reviews Wallace's albums and themes from his recordings, ending in a testament to his dead friend. Article three reminisced about cookouts and good times with Wallace, saying "B.I.G. dug Cali[fornia]" (Toure 1997). The author believed the East Coast/West Coast rivalry was over and expresses shock at the killing. Article four expresses outrage at lack of "niggas...giv[ing] a good goddamn" about the numerous murders taking place in black communities (Danyel Smith 1997). The feature topic is the Soul Train Awards that Wallace attended just hours before the shooting. The author chides the ceremony for not asking for a moment of silence in recognition of Tupac and the audience for simply "cheer[ing] like fools" when his album won the R\&B/Rap Album of the Year. This lack of genuine concern is seen as precipitating Wallace's killing because it shows no effort on the part of community leaders to condemn violent behavior. Murder has become "absolutely okay and regular and normal," and until it ceases to be so, it will continue.

Rolling Stone gave little attention to Lauryn Hill's win at the Grammys, only mentioning the after party she attended in an article called "Grammy Notes." The Village Voice gave Hill a bit more coverage, though she is part of a larger story about albums of the year. The Grammys themselves are not mentioned. The author says Hill has broken the "hardcore thrust that's claimed blackness for years" and helped return black music to a more diverse state by reviving old sounds and blending them with new ones. The 
album is voted the Number 2 Album of the Year by the Annual Pazz and Jop Critics' Poll featured each year in the paper.

It is noteworthy that the hip-hop community has embraced this album along with mainstream audiences. There is an acknowledged crossover appeal of the music, which features Hill singing, not rapping, over hip-hop-style beats on a majority of the album. None of the previously examined articles compares Hill to other rap crossover acts like Will Smith or MC Hammer. Her music is framed as universally accepted by both critics and audiences alike.

Neither Rolling Stone nor the Village Voice featured any articles dealing with Eminem's nomination for Album of the Year honors.

\section{CONCLUSION:}

Hegemonic framing occurs in most media outlets, reinforcing the majority's values and culture. When relatively new and youth-oriented cultural phenomena like hiphop challenge the older generation's ideals and worldviews, institutions dominated by the majority will not usually embrace these changes. People involved with such movements represent a lifestyle out-of-step with the mainstream culture, causing reporters who are firmly planted in that culture to make assumptions about those in the minority. The "race card" is a critical factor in this framing; young blacks and Latinos are being covered by mostly older whites. Cultural and generational factors separate the journalists from their 
subjects, and these differences often lead to negative framing by the writer. The ultimate responsibility of the media is to inform the public about important and pressing events and issues in a fair and well-rounded fashion. This ideal often falls short of perfection in reality due to a number of factors. Accuracy, balance, completeness, detachment, and ethics are the key ingredients for a story free from bias according to Freedom Forum and Newseum chairman and CEO Charles Overby (Strike 1999). These five components give the coverage credibility and a sense of true clarity. Few if any of the stories examined in this study fully implement these principles in their text. One-sided coverage and the lack of detachment were the two most noticeable features of the stories, from the frequent quoting of the judge and prosecutors in the 2 Live Crew coverage to the barrage of adjectives aimed at Eminem's music (potty-mouthed, etc.). Hip-hop is the stuff of delinquents and criminals if you buy into the media's framing of it. There may be some good lingering in it somewhere, but for the most part hip-hop is part of the problem, not part of the solution. So where do we go from here?

The musical and cultural phenomenon called hip-hop shows no signs of slowing down any time soon, so more media coverage is inevitable. How the press covers this music and its practitioners in the future will do a great deal to influence mainstream culture's definitions and understanding of hip-hop. The music has been around long enough for many reporters to have actually listened to and grown up with it. The evolutionary process involved in social acceptance of a new style of music usually takes a generation to occur. Jazz was originally called "immoral" by parents, whose children in turn embraced it and called rock and roll “immoral." Hip-hop is this generation's version 
of that, rebel music that angers parents (both black and white) and often creates separation between generations. "Some fans of rap may feel distressed that the academy is showing an interest in rap, and view it as a sign that rap is dying as a vital cultural medium. This should not be of any concern. Eventually, new forms of resistance will surely emerge and take its place" (Hemmer 1998). Maybe when this next controversial genre appears, taking hip-hop's place, this music will be viewed in the historical hindsight that all musical developments eventually are, regardless of popular press coverage at the time. Until then, hip-hop is contemporary culture's musical demon, adored by adolescents and despised by parents. The role the mass media play in influencing public perception of hip-hop is unclear, but the messages being put forth by the media are quite clear: hip-hoppers are bad boys making bad music. 
TABLES:

\section{(Table 1)}

\section{Artist}

Jazzy Jeff \&

Fresh Prince

2 Live Crew

Tupac Shakur

Notorious B.I.G.

Lauryn Hill

Eminem

Articles in which word

appears at least once

\section{"Violence" "Controversy/Rivalry/Feud" "Arrest/Jail/Prison"}

$\begin{array}{ccc}0 \text { mentions } & 1 \text { mention } & 0 \text { mentions } \\ 0 \text { mentions } & 6 \text { mentions } & 14 \text { mentions } \\ 26 \text { mentions } & 4 \text { mentions } & 22 \text { mentions } \\ 8 \text { mentions } & 9 \text { mentions } & 7 \text { mentions } \\ 0 \text { mentions } & 0 \text { mentions } & 0 \text { mentions } \\ 4 \text { mentions } & 5 \text { mentions } & 0 \text { mentions }\end{array}$

$42 \%$

$47 \%$

$33 \%$

\section{(Table 2)}

Artist

Jazzy Jeff and Fresh Prince

2 Live Crew

Tupac Shakur

Notorious B.I.G.

Lauryn Hill

Eminem

Total
\# of stories on front page of section

1 of $4(25 \%)$

4 of $5(80 \%)$

7 of $8(88 \%)$

3 of $5(60 \%)$

4 of $6(67 \%)$

5 of $8(63 \%)$

24 of $36(66 \%)$ 


\section{(Table 3)}

\section{Source}

Artists

Authority Figures(Judges,

Prosecutors, Sheriffs, etc.)

Friends and Fans

Witnesses

Lyrics Quoted From Artist's Album

Industry Analyst/ Activist

Store Owners

Lawyer for Artist

\section{\# of quotations}

17

15

8

3

8

12

4

4

\section{(Table 4)}

(Crime-related stories[2 Live Crew, Tupac Shakur, and Notorious B.I.G.])

Source

Artists

Authority Figures

Friends and Fans

Witnesses

Lyrics from Artist's Albums

Industry Analysts/ Activists

Store Owners

Lawyer for Artist

\section{\# of quotations}

9
15
7
3
5
7
4
4

(Table 5)

\section{Word count}

499 or less

500-999

1,000-1,499

1,500-1,999

2,000 or more
\# of articles

7

13

9

3

4* (All include listings of Grammy nominees or winners) 


\section{BIBLIOGRAPHY OF NEWSPAPER ARTICLES:}

AP. "Federal Judge Rules Rap Album Violates County's Obscenity Law.” New York Times, 7 Jun 1990, sec. D (National Desk), p. 22.

AP. “Rapper Shakur Dies of Gunshot Would at 25.” Miami Herald, 14 Sep 1996, sec. A, p. 1.

Baker, Soren. "The $43^{\text {rd }}$ Annual Grammy Nominations." Los Angeles Times, 4 Jan 2001, sec. F (Entertainment), p. 54.

Balducci, Leslie. "Shakur Lived Thug Life, Died Thug Life.” Chicago Sun-Times, 15 Sep 1996, sec. News, p. 6.

Boucher, Geoff. "Eminem's Grammy Nod Strikes a Blow For, and To, the Critics." Los Angeles Times, 4 Jan 2001, sec. A, p. 1.

Boucher, Geoff. "Grammy Awards; Hill Makes History with 5 Wins." Los Angeles Times, 25 Feb 1999, sec. A, p. 1.

Cobo-Hanlon, Leila. "Hip-Hop's Hill, Madonna Win Big Ricky Martin Gets Grammy." Miami Herald, 25 Feb 1999, sec. A, p. 1.

Cohen, Howard. "Hard-Core Rap Acts Grab Grammy Slots." Miami Herald, 4 Jan 2001, sec. A, p. 1.

Constable, Pamela. "Rapper Dies of Gunshot Wounds From Shooting; Drive-By Assault in Las Vegas Ends Tupac Shakur's Short, Violent Life." Washington Post, 14 Sep 1996, sec. A, p. 1.

Derogatis, Jim. “Grammys Push Envelope.” Chicago Sun-Times, 4 Jan 2001, sec. Features, p. 33.

Gundersen, Edna. "Grammy Race Too Close to Call; Diverse Offerings Fill Jumbled Field." USA Today, 4 Jan 2001, sec. D (Life), p. 1.

Gundersen, Edna. "Grammy: Women's Work, Done Hill Wins Record Five; Madonna Gets a Trio." USA Today, 25 Feb 1999, sec. D (Life), p. 1.

Gundersen, Edna and Anne Ayers. "Here's the Rap-up of Grammy Parties." USA Today, 24 Feb 1989, sec. D (Life), p. 2. 
Gundersen, Edna, Bruce Haring, and Ann Oldenburg. "The Rap About Tupac: Life of Conflicting Images Comes to a Violent End.” USA Today, 16 Sep 1996, sec. D (Life), p. 1.

Harrington, Richard. "Lauryn Hill: Give Her Five; Hip-Hop Star Breaks a Record For Women.” Washington Post, 25 Feb 1999, sec. C (Style), p. 1.

Harrington, Richard. 'McFerrin Wins 4 Grammys; 'Don't Worry' Tops Awards, Tracy Chapman Takes 3, Best New Artist." Washington Post, 23 Feb 1989, sec. C (Style), p. 1.

Hilburn, Robert and Jerry Crowe. "Rapper Tupac Shakur, 25, Dies 6 Days After Ambush.” Los Angeles Times, 14 Sep 1996, sec. A, p. 1.

Hilburn, Robert. "The $41^{\text {st }}$ Annual Grammy Awards; Hip-Hop: No Bad Rap Anymore." Los Angeles Times, 25 Feb 1999, sec. A, p. 16.

Hilburn, Robert. "The 43 ${ }^{\text {rd }}$ Annual Grammy Nominations; Analysis; A Milestone For Eminem-And Recording Academy." Los Angeles Times, 4 Jan 2001, sec. F (Entertainment), p. 53.

Hunt, Dennis and Steve Hochman. "Grammys '89; Backstage Harmony: Talk About Rap and a Boycott Flap..." Los Angeles Times, 23 Feb 1989, sec. A, p. 28.

Lichtblau, Eric, Chuck Philips, and Cheo Hodari Coker. "Gangsta Rap Performer Notorious B.I.G. Slain.” Los Angeles Times, 10 Mar 1997, sec. A, p. 1.

Milloy, Courtland. “At a Loss Over Shakur's Two Faces.” Washington Post, 15 Sep 1996, sec. B (Metro), p. 1.

Parales, Jon. "Grammys to McFerrin and Chapman." New York Times, 23 Feb 1989, sec. C (Cultural Desk); p. 20.

Parales, Jon. “Tupac Shakur, 25, Rap Performer Who Personified Violence, Dies.” New York Times, 14 Sep 1996, sec. A, p.1.

Parker, Laura. "Federal Judge Finds Rap LP Obscene; Fla. Record Sellers Subject to Arrest." Washington Post, 7 Jun 1990, sec. A, p. 1.

Philips, Chuck. "Florida Judge Rules 'Nasty’ Album Obscene; Lyrics: The Ruling Opens Door for Prosecution in Three Florida Counties of Retailers Who Sell the 2 Live Crew Rap Album.” Los Angeles Times, 7 Jun 1990, sec. F (Entertainment), p. 1. 
Pitts, Jr., Leonard. “A Sense of Decay Looms in Our Culture.” Miami Herald, 14 Sep 1996, sec. G (Living), p. 1.

Pitts, Jr, Leonard. “Another Rapper Falls Victim to Violence: Death is Walking Strong in Today’s Hip-Hop Culture.” Miami Herald, 10 Mar 1997, sec. A, p. 1.

Purdam, Todd. "Rapper is Shot to Death in Echo of Killing 6 Months Ago." New York Times, 10 Mar 1997, sec. A, p. 1.

Segal, David. "Grammy Nods in All Directions; Dr. Dre, Beyonce Knowles Lead List of Nominees." Washington Post, 4 Jan 2001, sec. C (Features), p.1.

Strauss, Neil. "Broad Field, No Standout in Grammy Nominations.” New York Times, 4 Jan 2001, sec. E, p. 1.

Strauss, Neil. "5 Grammys to Lauryn Hill; 3 to Madonna." New York Times, 25 Feb 1999, sec. A, p. 25.

Waxman, Sharon and Esther Iverem. “'Gangsta' Rap Singer Slain in L.A., Notorious B.I.G. Killing Similar to Shakur Death.” Washington Post, 10 Mar 1997, sec. A. p. 1.

Waxman, Sharon and Esther Iverem. "Rapper B.I.G. Killed in Drive-by." Chicago SunTimes, 10 Mar 1997, sec. News, p. 4.

Yancey, Kitty Bean and Anne Ayers. "2 Live Crew Group Facing Obscenity Rap. USA Today, 11 Jun 1990, sec. A, p.1.

Zimmerman, David and Anne Ayers. "Will 2 Live Crew Arrests Muffle Explicit Music?" USA Today, 11 Jun 1990, sec. D (Life), p. 1. 


\section{BIBLIOGRAPHY OF ALTERNATIVE PRESS COVERAGE:}

\section{Village Voice:}

Anson, Sam Gideon and Charles Rappleye. "Rap Sheet." 18 Mar 1997, 36.

Christgau, Robert. “The 1998 Pazz \& Jop Critics’ Poll.” 2 Mar 1999, 77.

George, Nelson. "Master of His Own Fate.” 24 Sep 1996, 28.

Hampton, Dream. "Real Niggaz Do Die.” 24 Sep 1996, 28.

Hinds, Selwyn Seyfu. "Party Over.” 128 Mar 1997, 36.

Simmons, Doug. "How To Rap Dirty and Influence People." 19 Jun 1990, 95.

Smith, Danyel. "Murder Won.” 18 Mar 1997, 39.

Smith, R.J. “To Live and Die in L.A.” 18 Mar 1997, 39.

Stovall, Natasha. "Death Row.” 24 Sep 1996, 29.

Stovall, Natasha. “Town Criers.” 18 Mar 1997, 42.

“The 1988 Pazz \& Jop Critics’ Poll.” 28 Feb 1989, 5.

Toure. "It was a Wonderful World.” 18 Mar 1997, 37.

Toure. "School's Out." 24 Sep 1996, 30.

\section{Rolling Stone:}

Bozza, Anthony. "Grammy Notes.” 15 Apr 1999, 28.

Gilmore, Mikal. "Easy Target.” 31 Oct 1996, 49.

Handelman, David. “...And Justice For Few.” 6 Apr 1989, 15.

Hendrickson, Matt, and Blair Fischer. "Notorious B.I.G.” 17 Apr 1997, 29.

Neely, K. "Rockers Sound Off." 9 Aug 1990, 27.

Ressner, J. and C. Carroll. “On the Road With Rap's Outlaw Posse.” 9 Aug 1990, 19. 
Soocher, S. "2 Live Crew: Taking the Rap.” 9 Aug 1990, 19.

“The Issue is Fear.” Pg. 24, (Aug 9 1990). 


\section{BIBLIOGRAPHY:}

Adkins, Tim. "Culture Thief? Confession of a White Negro Who Came to Save HipHop." Urban Think Tank website, (2001). Available online at: www.urbanthinktank.org/culturethief.cfm

Altheide, David. "Format and Symbols in TV Coverage of Terrorism in the United States and Britain.” International Studies Quarterly 31 (1987): 163.

. "Impact of Format and Ideology On TV News Coverage of Iran." Journalism Quarterly 62 (Summer 1985): 347.

Andersen, Neil. "Adolescent Culture and Music.” Emergency Librarian 24 (Nov/Dec 1996): 30.

Chideya, Farai. “All Eyez On Us.” Time 149 (Mar 24, 1997): 47.

Dyson, Michael Eric. Between God and Gangsta Rap: Bearing Witness to Black Culture. (New York: Oxford Univ. Press, 1996), 180.

Entman, Robert. "Framing U.S. Coverage of International News: Contrasts in Narratives of the KAL and Iran Air Incidents." Journal of Communication 41 (Autumn 1991): 6-24.

. The Black Image in the White Mind. (Chicago: University of Chicago Press, 2000), 90.

Forman, Murray. "Media Form and Cultural Space: Negotiating Rap Fanzines." Journal of Popular Culture 29 (Fall 1995): 171.

Gayle, Addison. "The State of Black Music and Literature at the Present Time." Crisis (1980) 179, 558.

Geier, Thom. "The Killing Fields in Rap's Gangsta-land." US News and World Report 122 (Mar 24 1997): 32.

Gilmore, M. and A. Karl. “The Year in Music.” Rolling Stone 593-594 (Dec 13 1990Dec 27 1990): 13.

Gissler, Sig. "Newspaper's Quest for Racial Candor." Media Studies Journal (Summer 1994): 123. 
Gold, J. "Day of the Dre: Dr. Dre and His Protégé, Snoop Doggy Dogg, Take Hardcore Rap From South Central Los Angeles To Your House." Rolling Stone 109, (Sept 30 1993): 38.

Goffman, Erving Frame Analysis: An Essay on the Organization of Experience. (Cambridge: Harvard Univ. Press, 1974), 21.

Hacker, Andrew. “Are the Media Really 'White'?” Media Studies Journal (Summer 1994), 84.

Hemmer, Kurt. "Look Who's Listenin', Rap, Black Culture, and the Academy." Melus (Fall 1998): 4. Available online at:http://www.findarticles.com/cf_0/m2278/3_23/54925307/print.jhtml

Jones, Quincy. “50 Years of Black Music.” Ebony 51 (1995): 179.

Miller, John J. "Immigration, the Press and the New Racism." Media Studies Journal (Summer 1994), 21.

Nelson, Jill. “The Rap on Tupac.” The Nation 263, (Oct 21, 1996): 10.

Nelson, T.E., R.A. Clawson, and Z.M. Oxley. "Media Framing of Civil Rights Conflict and Its Effect on Tolerance." American Political Science Review 91 (1997), :567583.

Parker, Laura. "Federal Judge Finds Rap LP Obscene." Washington Post (June 6 1990):A1

Reynolds, J.R. "Rap Confab Assembles Nation.” Billboard 107 (Nov 11 1995): 26.

Rose, Tricia. Black Noise: Rap Music and Black Culture in Contemporary America. (New Hampshire: University of New England Press, 1994).

Robinson, Ruth Adkins. "Hip-Hop History.” Billboard 111 (Dec 4, 1999): 38.

Sachs, Andrea and Susanne Washburn. "Tough Talk on Entertainment." Time 145 (Jun 12, 1995): 32 .

Shabazz, Julian L. "A Public Challenge on the Issue of Rap Music: The Conspiracy to Destroy Rap Will Be Met With a Frontal Assault." The Roc 15 (1997): Available online at: www.theroc.org/roc-mag/textarch/roc-15/roc15-03.htm 
Shoemaker, Pamela J. and Stephen D. Reese. Mediating the Message: Theories of Influence on Mass Media Content. (New York: Longman Press 1991), 150.

Strike, Sam. "5 Watchwords of Fairness Can Help Journalists, Overby Says." Freedom Forum website: (Feb 26 1999). Available online at: www.freedomforum.org/professional/1999/2/26watchwords.asp

Tuchman, Gaye. Making News: A Study in the Construction of Reality. (New York, Free Press 1978), ix, 7.

White, Armond. "On the Charts, Off the Covers." Nation 265 (Aug 25 1997): 17.

Williams, G. "Egomania in the Though of Antonio Gramsci: Some Notes on Interpretation." Journal of the History of Ideas 21 (1960): 587. 